The Social Sciences 14 (10): 341-345, 2019

ISSN: $1818-5800$

(C) Medwell Journals, 2019

\title{
The 2010 Law on Dissemination and Free Access to Information Focusing on Sustainable Development of Civil Society and FOIA
}

\author{
${ }^{1}$ Ali Asadzadeh and ${ }^{2}$ Mir Sajjad Seyyed Mousavi \\ ${ }^{1}$ Department of Law East Azarbayjan Science and Research Branch, \\ Islamic Azad University, Tabriz, Iran \\ ${ }^{2}$ Department of Law, Tabriz Branch, Islamic Azad University, Tabriz, Iran
}

\begin{abstract}
Freedom of information is a basic requirement of freedom of expression in modern world. The right to freedom of expression is one of the important indicator of human rights. It is noteworthy that both these rights are inherent human rights. Freedom of information is the right of citizens to free access to information held by government institutions. Freedom of information is one of the most important achievements of human rights which is closely related to freedom and transparency of information. The most important effect of freedom of information is the right to free and easy access to information; however, this right is restricted in some cases. Although, recognition of the right to freedom of information is evident in the Iranian legal system, adoption of the law on dissemination and free access to information and its executive regulations can be considered as the first and most serious attempt in this field. By archival review of the written documents, this study addresses FOIA in the light of sustainable development focusing on the law on dissemination and free access to information. Hence, this study first describes the legal nature of FOIA and its role in the Iranian legal system and distinguishes the concept of free access to information from other similar concepts. Then, this study discusses and analyzes freedom of information and its interference with privacy as well as limitations and exceptions to FOIA. Finally, its provisions, strengths and weaknesses as well as its enforcement are overviewed. It is noteworthy that adoption of FOI and its executive regulations, recognition of this right of Iranian citizens and emphasis on duty of the government to provide information to citizens is an important, significant and effective step in paving the way for freedom of information and free access to information.
\end{abstract}

Key words: Information, freedom of information, right to access, privacy, dissemination law, transparency

\section{INTRODUCTION}

One of the known human rights in modern societies is the right to access to information and freedom of information. Historically, this right has long roots in law worldwide; however, it was first codified and written as a sign of democracy in Switzerland in 250 years ago. At that time, the discussion was that democracy required indicators among which the most important was the right of access to information as well as the right to free dissemination of information.

Freedom of information is an important factor of government transparency. Transparency in government facilitates control of interactions between public institutions. Awareness and insight of outsider observer and controller are the prerequisite for monitoring and control, resulting from transparency. The increased public perception eliminates mismanagement or concealment of mismanagement.

Under freedom of information, general information and particularly the information held by government agencies must be allowed freely for individuals and should not be restricted except in some cases. A mere numerical majority no longer makes decisions but it is the absolute majority well aware of society that makes democratic decisions. Hence, freedom of information is known as the oxygen of democracy.

Among foundations of democracy, the free flow of information or freedom of information has attracted special attention in recent years. The right of public access to official information or the ability of citizens to access information held by government is called freedom of information. According to the Freedom of Information Act (FOIA), the government demands the lawmaker to allow access to documents and reports for a certain period; however, this right is not unconditional and requires some criteria. FOIA excludes the information involved in disclosures on issues such as foreign relations, national security, business activities of government and private affairs. Regulation of the flow of information associated with wise and logical principles of privacy will effectively contribute to protection of confidential information. In other words, one of the ideas of free access to information is better and more effective protection of 
privacy through regulation of its exceptions. Moreover, some governments consider expenses for this right. Therefore, this right requires citizens to pay for executive costs before gaining access to the information they are looking for.

Since, 1980's, global authoritarianism has been vanishing. Emergence of new democracies has led to new legislations which guarantee certain protections of the right to information.

Roger Clausse, Belgian professor of communication sciences, introduced the concept of freedom of information and addressed the emergence of the new term 'the right to freedom of information': 'along with freedom of information in a logical continuation of freedom of opinion and expression and freedom of press which includes information, a new concept and a potential right as a public right is characterized for awareness of events or the right to information. The latter concept indicates that the traditional freedoms are no longer sufficient. This concept add, so, there lements such as truth and objectivity of news, information integrity and public access to products of communication and publishing institutions to elements of freedom of information which represent means of transmitting news.

\section{CONCEPT OF FREEDOM OF INFORMATION}

Freedom of information which is misleading in content is a term that was first forged in America (Puddephatt, 2005). One might think the purpose of this kind of freedom is the access to all information while freedom of information refers to the right to public access to the information held by public institutions. This leads to the right of access to information which is a product of freedom of information. The right to access to information allows each member of the society to demand access to information held by public and private institutions at all times and requires institutions to provide the documents unless they have specific reasons. However, the terms 'restricted access to information' or 'privacy situation' are explained in the next sections.

Some countries use more accurate term which represents its content; for example, France use the term 'freedom of access to administrative documents' and Canada use 'access to information'. In Iranian law, the term 'law on dissemination and free access to information' is used. In the following, FOIA, its nature and evolution of legal principles are discussed.

Legal nature of FOIA: Aside from its appellation and with the connivance of multiple encounters of associations claiming to support freedom of press, FOIA is undoubtedly the starting point of all discussions regarding the rights of communication and press. FOIA requires accepting that all the processes of communication, from access to information to dissemination of information are authorized and the legislature is not required to authorize them specifically. Islam does not inhibit freedom of thought and information; instead, Islam requires people to be informed of the facts of life and believes in freely evaluation of different ideas and different opinions to achieve better and correct way of life. As Imam Ali (PBUH) says, those who are faced with different opinions will recognize the incorrect from the correct.

Requirements of FOIA: Undoubtedly, FOIA is the starting point of all discussions regarding the rights of communication and press. FOIA requires accepting that all the processes of communication from access to information to dissemination of information are authorized and the legislature is not required to authorize them, specifically. Restrictions and prohibitions must be declared, not vice versa.

For actualization of freedom of information, it is essential to provide preparations and adherence to its requirements. The requirements to enforce freedom of information are listed as follows:

- Expansion of the scope of freedom of information (Ansari, 2007)

- Restriction or prohibition of the destruction of government documents and records

- No requirement for the applicant to provide reason

- Adoption of promotional measures and opposition to secretism

- $\quad$ Proactive notification

- $\quad$ Reformation of the laws inconsistent with reasonable and legal information

- $\quad$ Legitimacy and accuracy of exceptions to freedom of information

- $\quad$ Protection of persons who disclose government errors

- Objection to government departments in ignoring requests for access to information

- $\quad$ Public government meetings

- Facilitation of public access to government information(Ansari, 2007)

- $\quad$ Easy access to scientific papers and research

One of the important advantages of freedom of information is that publications are cited more and accelerate the research for following reasons:

- $\quad$ Scientists and researchers do not pay for articles

- By eliminating the cost and restrictions related to authorization, free access facilitates the use of resources

In the era of printing, free access was impossible both physically and economically; however, the advent of the internet allows production of journal articles without 
waiting for payment with electronic publishing and free and online accessibility of scientific and peer-reviewed articles.

Free access archives and journals are useful, legal and permissible. The cases implemented around the world prove the fact that free access journals outperform traditional subscription-based journals in terms of cost-effectiveness and service to science.

\section{RIGHT TO ACCESS TO INFORMATION}

The right to access to information is inseparably related to right to freedom of expression. Therefore, the texts relating to this discussion often stress this easy and impossible argument that freedom of expression is meaningless if there is nothing for expression (Eshaghi, 2005).

The right of access to information is the product of freedom of information; in other words, it is a framed freedom. Each member of the society can demand access to information held by public and sometimes private institutions at all times and the institutions can reject the demands only by recognized reasons.

The most fundamental principle of a country is democracy through which citizens can monitor the behavior of government and governors. However, it does not occur in vacuum. This requires free access of citizens to information.

The fact is that more active roles and greater responsibilities require their means. People should be able to think based on reliable and comprehensive information and formulate their ideas freely. This approach entails changes in historical role of the government. Previously, the government exclusively and solely analyzed data based on their goals while they now must share their knowledge with the public.

Meanwhile, governments traditionally preserved information; in the light of freedom of information and access, however, they will gradually become the 'information medium'. This is why this change in historical role arouses oppositions against freedom of information between government agencies.

Naturally, no one can give others the arbitrary dominance on self. Even in societies where democracy does not exist, it is necessary for people to monitor government performance. Certainly, people have the right to monitor the government in societies in which sovereignty is the right of people (Katoozian, 2005).

The right of access to information is specifically recognized in constitutions of Argentina, Slovenia, Bulgaria, Peru, Thailand, the Republic of South Africa, Romania, the Russian Federation, Philippines, Poland, Lithuania, Malawi, Hungary and Moldova. This right is either explicitly considered and specified in the constitution or recognized by interpreting the provisions of the constitution by the Supreme Court.
The constitution of the Islamic Republic of Iran states that: 'The purpose of government is to develop human towards the divine system to allowdevelopment of talents in order to manifestdimensions of human race and this only depends on active and full participation of the society in this process of social development'.

Exceptions to FOIA: It is also an accepted principle that FOIA should not threaten public and private interests. Therefore, the law must clearly specify exceptions. However, broad and vague exceptions eliminate the concept of freedom of information. Resorting to exceptions is the most common way to neutralize FOIA and the right of access.

Against general principle of freedom of information, some cases known as FOIA exceptions are also considered; one of these exceptions is national security. National security is known as the most important exception of freedom of information; accordingly, access to the information which can threaten national security is prohibited. For this reason, different countries adopt different measures to prevent the access of citizens to security information (Ansari, 2007).

National security requires governmentsto prevent any action which threatens security and punishthose actions against national security. Access to security information held by public institutions is one of the factors whichcan provide the groundwork for a national security threat. For this reason, different countries prevent the access of citizens to security information by two basic actions: exclusion of security information from the scope of freedom of information and exclusion of security agencies from the realm of freedom of information.

Despite the wide and frequent use of the term 'national security' in military, economic, political and social texts and existence of multiple definitions, it is still difficult to provide a clear and comprehensive definition of national security.

Outcomes of FOIA: In Iran, the primary draft of FOIA was presented in 2001 by the High Council of Informatics in 8 chapters and 83 articles. This was in line with a briefing paper and some remarks about the necessity of this law. The organization has tried to design a legal framework for this concept because it believes that the law will remain a scientific debate as long as it lacks a clear legal framework. According to the High Council of Informatics, access to government information is one of the most important principles of human rights at the beginning of the 21st century (Tabatabaei-Motameni, 2003). Those government structures which cannot ensure free public access to information violatehuman rights. However, the council does not believe in absolute freedom and considers restrictions such as protection of public interests, protection of third party and protection of 
agencies for decision-making and avoiding cost and workload. This draft was submitted to the government in October 2003 and was approved in 6 chapters and 36 articles on July 2005.

Freedom of access to information legislation was taken in public sessions of the Parliamentin August 16, 2005 and reviewed by 15major and minor commissions, including Cultural Commission. The legislation on dissemination and free access to information, originally called as freedom of information legislation was finally voted.

The legislation in 150-160 pages was on the agenda of the cultural commission and its details were finalized. However, given that the legislation prohibits illegal filtering of news websites which is the basic principle of freedom of access to information, there were rumors of the reclamation of the legislation by the government. In short, the legislation was enacted in 2009 by the 8th Parliament and was presented to the Guardian Council which objected to 7 cases. The Parliament corrected 5 cases. Finally, due to differences between the Parliament and the Council on Articles 6 and 11 of the legislation, it was presented to the Expediency Council which removed the Article 6 that required private institutions to provide public accessto their information. Article 11 which required public institutions to provide their information, balance work and computer data as far as possible in aguidebook to the public was approved with an additional clause.

Finally, the legislation was enacted by the Expediency Council in August 2009 in six chapters including definitions and generalities, access to information procedure, promotion of transparency, exceptions to access to information, the Commission on Freedom of Information and civil and criminal responsibilities in 36 articles. From the original legislation submitted to the 6th Parliament, the sixth chapter was removed and chapters 7 and 8 were merged. The final legislation was delivered tothe Ministry of Culture and Islamic Guidance for implementation in January 31, 2010.

\section{CONCLUSION}

Given the above, it can be concluded that freedom of information should be recognized and supported for its many positive economic, social, political, legal and cultural advantages; however, these advantages may fail unless its requirements are known.

Recognition of freedom of information as a fundamental human right is followed by two important outcomes: first, information is not a tool to serve the interests of rulers and policy makers; instead, it should be used in order to serve the public interest. Second, FOIA allows public access to maximum freedom of information and those who believe in exceptions to this right should give reasons for their claims.
The right of access to information is the product of freedom of information in other words. Each member of the society can demand access to information held by public and sometimes private institutions at all times and the institutions can reject the demands only by recognized reasons.

Responsibilities of public and private institutions in providing information to citizens are clearly determined inexecutive procedures and provisions of the law. However, FOIA has limitations and exceptions which restrict the right to free access to information.

Exceptions to FOIA and the right to free access to information must be accurately predicted in law. None of the government agencies should be completely excluded from the scope of FOIA, even if their most functions are in the range of exceptions. This applies to all sectors of government (legislative, executive and judiciary) as well as all functions of government (including defense and security intelligence agencies). Non-disclosure of information should be justified case by case.

However, FOIA is in conflict with privacy of individuals in some cases. Thus, itis necessary to take precautions. However, an emphasized exception to FOIA is privacy. Therefore, this area requires policy makers and decision makers to vindicate the legitimate rights of citizens by logical and realistic approaches.

Realization of freedom of information requires different software and hardware infrastructure which is not provided by legislation. In developing countries, laws on freedom of information are very progressive in terms of legal standards in practice, their implementation is faced with numerous obstacles. The law on dissemination and free access to information and its executive regulations does not focus on the concept, premises and requirements of freedom of information. It seems essential todo further and more accurate investigations and provide effective solutions.

\section{RECOMMENDATIONS}

Strengthening and developing regulatory frameworks, such asfreedom of information and protection of disclosure rules (in which social and national valuesare reflected), supporting coordination between governments in developing regulatory frameworks and minimizing the lack of coordination in this area.

Providing citizens with information, including information provided by international organizations to meet global public interest,in the form of procedures for implementation of the 2010 Act of Dissemination and Free Access to Information.

Exchanging with countries, organizations and stakeholders who share knowledge, optimize resources and encourage partnerships. Negotiating to ensure that the information sharing is reflected in the universal laws. 
Encouraging cooperation between governmental and non-governmental organizations (Food and Agricultural Organization, International Telecommunication Union, United Nations Development Programme, World Bank, etc.) to build a body of knowledge which can be achieved worldwide from the mass of information produced in development projects, particularly for the sake of developing countries.

Developing an international list of laws, regulations and action plans regarding production and dissemination of public information in close cooperation with organizations such as the World Intellectual Property Organization.

Using electronic and digital instruments form freedom of information and the right to public access to all legitimate information. Determining an agency to investigate offenses referred to Article 12 of the Law on Dissemination and Free Access to Information.
Preventing the escape of the rule of law because of conflict with personal interests of people by monitoring the meetings.

\section{REFERENCES}

Ansari, B., 2007. Mass Communication Rights. 1st Edn., Publisher SAMT Publications, Tehran, Iran,.

Eshaghi, S., 2005. Freedom in Islam and the West. 1st Edn., Islamic Research Center of Radio and Television, Tehran, Iran,.

Katoozian, N., 2005. Philosophy of Law. S.l.S.n. Publisher, Tehran, Iran,.

Puddephatt, A., 2005. Freedom of Expression, the Essentials of Human Rights. Hodder Arnold, London, England, Pages: 127.

Tabatabaei-Motameni, M., 2003. Public Freedoms and Human Rights. 3rd Edn., Tehran University Press, Tehran, Iran, (In Indonesian). 